\title{
ANALISIS PERBEDAAN PELAPORAN CSR PADA BUMN DAN BUMS YANG TERDAFTAR DI BEI TAHUN 2014
}

\author{
Heny Sidanti \\ Alfian Syaikhori M \\ Universitas PGRI Madiun \\ fians_5vers@yahoo.com
}

\begin{abstract}
The purpose of this study was to analyze the empirical evidence of differences in reporting Corporate Social Responsibility (CSR) in state-owned enterprises and private enterprises listed on the Stock Exchange in 2014. This research is a quantitative research. The study population was BUMN and BUMS listed in the Indonesia Stock Exchange (BEI). Samples are 22 companies consisting of 12 BUMN companies and 10 companies BUMS listed in the Indonesia Stock Exchange (BEI). The analysis technique used using independent samples t-test. The results showed that there was no significant difference between Corporate Social Responsibility (CSR) of the company's state-owned enterprises with private enterprises in terms of economic sectors. A description of the analysis showed that CSR BUMN in sectors of the economy is greater than the company BUMS, but the differences were considered less significant. There were no significant differences between the Corporate Social Responsibility (CSR) of the company's state-owned enterprises with private enterprises in terms of the environmental sector. A description of the analysis showed that CSR state-owned companies in the environmental sector is greater than the company BUMS, but the differences were considered less significant. There are significant differences between the Corporate Social Responsibility (CSR) of the company's state-owned enterprises with private enterprises in terms of the employment sector. A description of the analysis showed that CSR state-owned enterprises in the employment sector is greater than the company BUMS, and the difference is considered to be very significant CSR.
\end{abstract}

Keywords : $B U M N$, BUMS, CSR

\section{PENDAHULUAN \\ Latar Belakang}

Pada awal September 2015, ada penyelewengan dana Corporate Social Responsibility (CSR) pada perusahaan BUMN. Perusahaan tersebut adalah BNI, BRI, PT Askes, PT Pertamina, PT Pelabuhan Indonesia II, PT Hutama Karya, dan PT Perusahaan Gas Negara. Ada korupsi sekitar Rp126 miliar dalam pelaksanaan CSR PT Pertamina tahun 2012-2014 dengan nilai anggaran Rp. 251 miliar yang disalurkan oleh Pertamina Foundation untuk kegiatan penanaman 100 juta pohon, beasiswa Sobat Bumi, sekolah Sobat Bumi, dan sekolah sepak bola Pertamina. Penggunaan dana Corporate Social Responsibility (CSR), yang sampai saat ini masih dianggap "wilayah abuabu" oleh sejumlah pihak dan pejabat sudah tidak relevan lagi penggunaannya di tahun ini. (108Jakarta.com).

Perusahaan sebagai pihak yang memanfaatkan sumberdaya alam, namun dalam pemanfaatannya dapat menimbulkan masalah sosial dan lingkungan dituntut untuk memenuhi 
pertanggungjawaban

Pertanggungjawaban sosial atau Corporate Social Responsibility (CSR) merupakan suatu tindakan yang dilakukan oleh suatu perusahaan untuk memenuhi tanggung jawab sosial maupun terhadap lingkungan.

Penerapan Corporate Social Responsibility (CSR) sudah menjadi kewajiban bagi perusahaan tidak hanya sekedar suka rela di sebabkan keluarnya undang-undang yang mengatur tentang hal ini, yakni Undang-Undang Republik Indonesia Nomor 40 tahun 2007 tentang Perseroan Terbatas pasal 74 ayat 1 yang menyatakan "Perseroan yangmenjalankan kegiatan usahanya di bidang dan atau berkaitan dengan sumber daya alam wajib melaksanakan Tanggung Jawab Sosial dan Lingkungan." Kewajiban pelaksanaan CSR juga diatur dalam UndangUndang Nomor 25 tahun 2007 tentang Penanaman Modal pasal 15 (b) yang menyatakan "setiap penanam modal berkewajiban melaksanakan tanggung jawab sosial perusahaan", dan pasal 17 yang isinya "penanam modal yang mengusahakan sumber daya alam yang tidak terbarukan wajib mengalokasikan dana secara bertahap untuk pemulihan lokasi yang memenuhi standar kelayakan lingkungan hidup, yang memenuhi standar kelayakan lingkungan hidup, yang pelaksanaannya diatur sesuai dengan ketentuan peraturan-peraturan perundang-undangan".

Sejauh ini, penelitian yang menganalisis hubungan desain program dan pelaporan CSR masih sedikit sehingga menarik bagi peneliti untuk meneliti gap research tersebut guna mengetahui sejauh mana hubungan struktur kepemilikan dengan desain program dan pelaporan CSR pada perusahaan (BUMN dan BUMS) di Indonesia. yang memiliki sistem hukum yang sama yaitu perseroan, namun dengan kepemilikan yang berbeda.

\section{Tujuan Penelitian}

Berdasarkan pemaparan la-tar belakang yang telah dikemukakan sebelumnya, maka tujuan penelitian ini adalah sebagai berikut:

1. Untuk menganalisis bukti empiris perbedaan pelaporan Corporate Social Responsibility (CSR) ekonomi pada BUMN dan BUMS yang terdaftar di BEI tahun 2014.

2. Untuk menganalisis bukti empiris perbedaan pelaporan Corporate Social Responsibility (CSR) lingkungan pada BUMN dan BUMS yang terdaftar di BEI tahun 2014.

3. Untuk menganalisis bukti empiris perbedaan pelaporan Corporate Social Responsibility (CSR) ketenagakerjaan pada BUMN dan BUMS yang terdaftar di BEI tahun 2014

\section{TINJAUAN PUSTAKA}

\section{Kajian Teori}

\section{Corporate Social Responsibility (CSR)}

Menurut (Untung, 2008:1), Corporate Social Responsibility (CSR) atau tanggung jawab sosial merupakan suatu sikap yang ditunjukkan perusahaan atas komitmennya terhadap para pemangku kepentingan perusahaan atau stakeholders dalam mempertanggungjawabkan dampak dari operasi atau aktivitas yang dilakukan perusahaan tersebut baik dalam aspek sosial, ekonomi, maupun lingkungan, serta menjaga agar dampak tersebut memberikan manfaat kepada masyarakat dan lingkungannya. 
Menurut The World Business Council for Sustainable Development (WBCSD), tanggung jawab sosial merupakan sebuah komitmen bisnis untuk memberikan konstribusi bagi pembangunan ekonomi berkelanjutan, melalui kerja sama dengan para karyawan serta perwakilan perusahaan, komunitas setempat maupun masyarakat umum untuk meningkatkan kualitas kehidupan dengan cara yang bermanfaat, baik bagi kelangsungan bisnis perusahaan maupun untukpembangunan. Tanggung jawab sosial yang dilakukan perusahaan ini berhubungan erat dengan pembangunan berkelanjutan, dimana suatu organisasi terutama perusahaan dalam melaksanakan aktivitasnya harus mendasarkan keputusannya tidak hanya berdasarkan dampaknya dalam aspek ekonomi, misalnya tingkat keuntungan atau deviden, melainkan juga harus menimbang dampak sosial dan lingkungan yang timbul dari keputusannya itu, baik untuk jangka pendek maupun untuk jangka yang lebih panjang.

\section{METODOLOGI PENELITIAN}

\section{Tempat dan Waktu}

Penelitian ini langsung melalui situs http://www.idx.co.id/. Penelitian ini mengambil periode pengamatan pada tahun 2014. Penggunaan situs http://www.idx. co.id/ karena terdapat data yang dibutuhkan yaitu laporan tahunan perusahaan BUMN dan BUMS yang terdaftar di Bursa Efek Indonesia (BEI).

\section{Populasi dan Sampel Populasi}

Populasi yang digunakan oleh peneliti dalam penelitian ini adalah perusahaan BUMN dan BUMS yang terdapat di Bursa Efek Indonesia (BEI).

\section{Sampel}

Sampel dalam penelitian ini adalah laporan tahunan dan Sustainability Report perusahaan BUMN dan BUMS pada tahun 2014 yang tercatat di Bursa Efek Indonesia. Perusahaan-perusahaan tersebut adalah 
Tabel 1

Sampel Perusahaan

\begin{tabular}{|c|c|c|}
\hline SEKTOR & BUMN & BUMS \\
\hline Energi & PT Perusahaan Gas Negara, Tbk & PT Indika Energy Tbk \\
\hline Kontruksi & $\begin{array}{l}\text { PT Pembangunan Perumahan } \\
\text { (Persero) Tbk } \\
\text { PT Wijaya Karya (Persero) Tbk }\end{array}$ & $\begin{array}{l}\text { PT Total Bangun Persada } \\
\text { Tbk } \\
\text { PT United Tractors Tbk }\end{array}$ \\
\hline Perbankan & $\begin{array}{l}\text { PT Bank Negara Indonesia } \\
\text { (Persero) Tbk } \\
\text { PT Bank Rakyat Indonesia } \\
\text { (Persero), Tbk } \\
\text { PT Bank Tabungan Negara } \\
\text { (Persero) Tbk } \\
\text { PT Bank Mandiri (Persero) Tbk }\end{array}$ & $\begin{array}{l}\text { PT Bank Danamon } \\
\text { Indonesia, Tbk } \\
\text { PT Bank CIMB Niaga Tbk }\end{array}$ \\
\hline Pertambangan & $\begin{array}{l}\text { PT Aneka Tambang Tbk } \\
\text { PT Bukit Asam (Persero) Tbk }\end{array}$ & $\begin{array}{l}\text { PT Indo Tambang Raya } \\
\text { Megah Tbk } \\
\text { PT Golden Agri Resources } \\
\text { Tbk }\end{array}$ \\
\hline Angkutan & PT Jasa Marga (Persero) Tbk & PT AKR Corporindo Tbk \\
\hline Telekomunikasi & $\begin{array}{l}\text { PT Telekomunikasi Indonesia } \\
\text { (Persero), Tbk }\end{array}$ & PT XL Axiata Tbk \\
\hline Semen & $\begin{array}{l}\text { PT Semen Indonesia (Persero) } \\
\text { Tbk }\end{array}$ & PT Holcim Indonesia Tbk \\
\hline
\end{tabular}

\section{Teknik Pengumpulan Data}

Data dikumpulkan dengan menggunakan metode content analysis, Content analysis dilakukan dengan cara melakukan observasi atas Sustainability ReportBUMN dan BUMS tahun 2014 di yang diperoleh melalui situs homepage Bursa Efek Indonesia (BEI) yaitu www.idx.co.id.

\section{Teknik Analisis Data \\ Metode Deskriptif}

Jenis penelitian yang digunakan dalam penelitian ini adalah penelitian deskriptif, karena dalam penelitian ini mendeskripsikan pengungkapan tanggungjawab sosial perusahaan BUMN. Penelitian deskriptif (descriptive research) adalah suatu metode penelitian yang ditujukan untuk menggambarkan fenomena-fenomena yang ada, yang berlangsung pada saat ini atau saat yang lampau.

\section{Uji Normalitas}

Uji normalitas data dilaksanakan dengan tujuan agar dapat memperoleh informasi mengenai data tersebut berdistribusi normal atau tidak. Selain itu, uji normalitas data juga akan menentukan langkah yang harus ditempuh selanjutnya, yaitu analisis statistik apa yang harus digunakan, apakah statistik parametrik atau nonparametrik. Langkah yang dilakukan adalah dengan menginput dan menganalisa data dengan menggunakan deskripsi explore yang terdapat pada descriptive stasistics di analyze data pada menu SPSS versi 22.

Uji normalitas dari output yang dihasilkan program SPSS versi 
22pada penelitian ini menggunakan uji Kolmogorov Smirnov (uji K-S). Berikut ini adalah langkah terkait ketentuan uji normalitas dalam kriteria keputusan:

a. Nilai sig, atau probabilitas < 0,05 (distribusi tidak normal),

b. Nilai sig, atau probabilitas > 0,05 (distribusi normal),

\section{Uji Homogenitas}

Uji homogenitas dilakukan untuk mengetahui apakah data yang digunakan dalam uji independent samples $t$-testmemiliki varians yang sama atau tidak. Output hasil pengolahan SPSS akan diperoleh untuk independent samples $t$-test ada dua hasil, yaitu uji varians yang berada pada kolom asumsi varians sama dan pada kolom asumsi varians tidak sama. Pengujian terlebih dahulu dilakukan dengan mencari apakah varians kedua kelompok sampel sama atau tidak. Ketentuannya adalah, apabila varians kedua kelompok sampel sama maka untuk pengujian rata-rata, nilai-nilai yang digunakan adalah pada kolom baris asumsi varians sama. Sebaliknya apabila hasil pengujian varians kedua kelompok tidak sama, maka untuk pengujian rata-rata nilai angkanya mengacu pada kolom baris asumsi varians tidak sama.

Kriteria Keputusan:

a. Nilai Sig. atau nilai probabilitas $<0,05$, data berasal dari populasi yang memiliki varians tidak sama (Tidak Homogen). b. Nilai Sig. atau nilai probabilitas $>0,05$, data berasal dari populasi yangmemiliki varians sama (Homogen).

\section{Uji Statistik t}

Uji perbedaan dilakukan dengan uji t. Uji statistik $t$ dalam penelitian ini digunakan untuk menunjukkan perbedaan pelaporanCorporate Social Responsibility (CSR) pada BUMN dan BUMS. Pengujian ini menguji signifikansi koefisien suatu perbedaan pelaporan CSR tersebut. Tingkat signifikansi yang digunakan dalam penelitian ini adalah 0,05 $(\alpha=5 \%)$. Syarat pengukuran hipotesis:

a. Jika t hitung > dari t tabel, (Ho di tolak Ha diterima)

b. Jika t hitung < dari t tabel, (Ho di terima Ha dtolak)

\section{HASIL PENELITIAN DAN \\ PEMBAHASAN \\ Statistik Deskriptif}

Untuk analisis deskripsi pada penelitian ini akan menjelaskan data Corporate Social Responsibility (CSR) dari masing-masing perusahaan BUMN dan BUMS sebagai berikut:
a. Corporate Social Responsibility (CSR) perusahaan BUMN
Data CSR pada sampel perusahaan BUMN yang terdaftar di Bursa Efek Indonesia (BEI) tahun 2014, dapat diringkas dalam bentuk tabel sebagai berikut: 
Tabel 2

Corporate Social Responsibility (CSR) perusahaan BUMN yang terdaftar di Bursa Efek Indonesia (BEI) tahun 2014

\begin{tabular}{|c|c|c|c|c|c|c|c|}
\hline \multirow[b]{2}{*}{ Sektor } & \multirow[b]{2}{*}{ Perusahaan } & \multicolumn{6}{|c|}{ Laporan CSR } \\
\hline & & Ekonomi & $\begin{array}{l}\text { Per } \\
\text { Sektor }\end{array}$ & Lingkungan & $\begin{array}{l}\text { Per } \\
\text { Sektor }\end{array}$ & $\begin{array}{l}\text { Tenaga } \\
\text { kerja }\end{array}$ & $\begin{array}{l}\text { Per } \\
\text { Sektor }\end{array}$ \\
\hline Energi & $\begin{array}{l}\text { PT Perusahaan Gas } \\
\text { Negara, Tbk }\end{array}$ & 55,5 & 55,5 & 50,0 & 50,0 & 62,5 & 62,5 \\
\hline \multirow[t]{2}{*}{ Kontruksi } & $\begin{array}{l}\text { PT Pembangunan } \\
\text { Perumahan } \\
\text { (Persero) Tbk }\end{array}$ & 100,0 & \multirow[t]{2}{*}{88,9} & 100,0 & \multirow[t]{2}{*}{65,0} & 100,0 & \multirow[t]{2}{*}{67,5} \\
\hline & $\begin{array}{l}\text { PT Wijaya Karya } \\
\text { (Persero) Tbk }\end{array}$ & 77,8 & & 30,0 & & 35,0 & \\
\hline \multirow{4}{*}{ Perbankan } & $\begin{array}{l}\text { PT Bank Negara } \\
\text { Indonesia (Persero) } \\
\text { Tbk }\end{array}$ & 55,6 & \multirow{4}{*}{50,0} & 13,3 & \multirow{4}{*}{32,5} & 57,5 & \multirow{4}{*}{46,9} \\
\hline & $\begin{array}{l}\text { PT Bank Rakyat } \\
\text { Indonesia (Persero), } \\
\text { Tbk }\end{array}$ & 66,7 & & 36,7 & & 62,5 & \\
\hline & $\begin{array}{l}\text { PT Bank Tabungan } \\
\text { Negara (Persero) } \\
\text { Tbk }\end{array}$ & 44,4 & & 50,0 & & 12,5 & \\
\hline & $\begin{array}{l}\text { PT Bank Mandiri } \\
\text { (Persero) Tbk }\end{array}$ & 33,4 & & 30,0 & & 55,0 & \\
\hline \multirow[t]{2}{*}{ Pertambangan } & $\begin{array}{l}\text { PR Aneka Tambang } \\
\text { Tbk }\end{array}$ & 55,6 & \multirow{2}{*}{44,5} & 76,7 & \multirow{2}{*}{50,0} & 52,5 & \multirow{2}{*}{31,3} \\
\hline & $\begin{array}{l}\text { PT Bukit Asam } \\
\text { (Persero) Tbk }\end{array}$ & 33,3 & & 23,3 & & 10,0 & \\
\hline Angkutan & $\begin{array}{l}\text { PT Jasa Marga } \\
\text { (Persero) Tbk }\end{array}$ & 55,6 & 55,6 & 13,3 & 13,3 & 35,0 & 40,0 \\
\hline Tekekomunikasi & $\begin{array}{l}\text { PT Telekomunikasi } \\
\text { Indonesia (Persero), } \\
\text { Tbk }\end{array}$ & 66,7 & 66,7 & 16,7 & 16,7 & 52,5 & 52,5 \\
\hline Semen & $\begin{array}{l}\text { PT Semen } \\
\text { Indonesia (Persero) } \\
\text { Tbk }\end{array}$ & 77,8 & 77,8 & 63,3 & 63,3 & 45,0 & 45,0 \\
\hline
\end{tabular}

b. Corporate Social Responsibility (CSR) perusahaan BUMS

Data CSR pada sampel perusahaan BUMS yang terdaftar di Bursa Efek Indonesia (BEI) tahun 2014, dapat diringkas dalam bentuk tabel sebagai berikut : 
Tabel 3

Corporate Social Responsibility (CSR) perusahaan BUMS yang terdaftar di Bursa Efek Indonesia (BEI) tahun 2014

\begin{tabular}{|c|c|c|c|c|c|c|c|}
\hline \multirow[b]{2}{*}{ Sektor } & \multirow[b]{2}{*}{ BUMS } & \multicolumn{6}{|c|}{ Laporan CSR } \\
\hline & & Ekonomi & $\begin{array}{c}\text { Per } \\
\text { Sektor }\end{array}$ & Lingkungan & $\begin{array}{c}\text { Per } \\
\text { Sektor }\end{array}$ & $\begin{array}{l}\text { Tenaga } \\
\text { kerja }\end{array}$ & $\begin{array}{c}\text { Per } \\
\text { Sektor }\end{array}$ \\
\hline Energi & $\begin{array}{l}\text { PT Indika } \\
\text { Energy Tbk }\end{array}$ & 22,2 & 22,2 & 6,7 & 6,7 & 15,0 & 15,0 \\
\hline \multirow[t]{2}{*}{ Kontruksi } & $\begin{array}{l}\text { PT Total } \\
\text { Bangun } \\
\text { Persada } \\
\text { Tbk }\end{array}$ & 77,8 & \multirow[t]{2}{*}{72,2} & 36,7 & \multirow[t]{2}{*}{35,0} & 50,0 & \multirow[t]{2}{*}{43,8} \\
\hline & $\begin{array}{l}\text { PT United } \\
\text { Tractors } \\
\text { Tbk }\end{array}$ & 66,7 & & 33,3 & & 37,5 & \\
\hline \multirow[t]{2}{*}{ Perbankan } & $\begin{array}{l}\text { PT Bank } \\
\text { Danamon } \\
\text { Indonesia, } \\
\text { Tbk }\end{array}$ & 55,6 & \multirow[t]{2}{*}{44,4} & 16,7 & \multirow[t]{2}{*}{18,3} & 52,5 & \multirow[t]{2}{*}{42,5} \\
\hline & $\begin{array}{l}\text { PT Bank } \\
\text { CIMB } \\
\text { Niaga Tbk }\end{array}$ & 33,3 & & 20,0 & & 32,5 & \\
\hline \multirow{2}{*}{ Pertambangan } & $\begin{array}{l}\text { PT Indo } \\
\text { Tambang } \\
\text { Raya } \\
\text { Megah Tbk }\end{array}$ & 77,8 & \multirow[t]{2}{*}{61,1} & 50,0 & \multirow[t]{2}{*}{41,7} & 35,0 & \multirow[t]{2}{*}{38,8} \\
\hline & $\begin{array}{l}\text { PT Golden } \\
\text { Agri } \\
\text { Resources } \\
\text { Tbk }\end{array}$ & 44,4 & & 33,3 & & 42,5 & \\
\hline Angkutan & $\begin{array}{l}\text { PT AKR } \\
\text { Corporindo } \\
\text { Tbk }\end{array}$ & 100,0 & 100,0 & 26,7 & 26,7 & 15,0 & 15,0 \\
\hline Telekomunikasi & $\begin{array}{l}\text { PT XL } \\
\text { Axiata Tbk }\end{array}$ & 33,3 & 33,3 & 10,0 & 10,0 & 22,5 & 22,5 \\
\hline Semen & $\begin{array}{l}\text { PT Holcim } \\
\text { Indonesia } \\
\text { Tbk }\end{array}$ & 100,0 & 100,0 & 113,3 & 113,3 & 32,5 & 32,5 \\
\hline
\end{tabular}

Sumber : data diolah

\section{Pembahasan}

Hasil penelitian ini menemukan temuan empiris terkait dengan tujuan penelitian, secara khusus ada tiga temuan penelitian yaitu:

Pertama, tidak terdapat perbedaan yang signifikan antara Corporate Social Responsibility (CSR) dari perusahaan BUMN dengan perusahaan BUMS ditinjau dari sektor ekonomi. Dari analisis deskripsi menunjukkan bahwa CSR perusahaan BUMN di sektor ekonomi lebih besar dibandingkan perusahaan BUMS, akan tetapi perbedaan tersebut dinilai kurang signifikan.Kategori kinerja ekonomi yang paling banyak diungkapkan adalah terkait dampak keuangan dan risiko lainnya akibat perubahan iklim serta peluangnya bagi aktivitas organisasi. Kemudian untuk nilai perolehan dan distribusi ekonomi langsung, meliputi pendapatan, biaya operasi, imbal jasa karyawan, donasi, 
dan investasi komunitas lainnya, laba ditahan, dan pembayaran kepada penyandang dana serta pemerintah.

Kedua, tidak terdapat perbedaan yang signifikan antara Corporate Social Responsibility (CSR) dari perusahaan BUMN dengan perusahaan BUMS ditinjau dari sektor lingkungan. Dari analisis deskripsi menunjukkan bahwa CSR perusahaan BUMN di sektor lingkungan lebih besar dibandingkan perusahaan BUMS, akan tetapi perbedaan tersebut dinilai kurang signifikan.Pada indikator lingkungan membahas tentang inisiatif untuk mendapatkan produk dan jasa yang berbasis energi efisien atau energi yang dapat diperbarui, serta pengurangan persyaratan kebutuhan energi sebagai akibat dari inisiatif tersebut dan indikator yang terkait inisiatif untuk mengurangi dampak lingkungan produk dan jasa dan sejauh mana dampak pengurangan tersebut menjadi indikator kinerja. Untuk beberapa indikator kinerja lingkungan yang membahas mengenai nilai keanekaragaman hayati kurang dijadikan informasi pengungkapan yang favorit. Hanya sedikit perusahaan yang melaporkannya, Hal ini menunjukkan bahwa perusahaan industri dasar dan kimia kurang memperhatikan dalam hal perbaikan terhadap alam.

Ketiga, terdapat perbedaan yang signifikan antara Corporate Social Responsibility (CSR) dari perusahaan BUMN dengan perusahaan BUMS ditinjau dari sektor ketenagakerjaan. Dari analisis deskripsi menunjukkan bahwa CSR perusahaan BUMN di sektor ketenagakerjaan lebih besar dibandingkan perusahaan BUMS, dan perbedaan CSR ini dinilai sangat signifikan. Terdapat 3 indikator kategori praktek tenaga kerja dan pekerjaan layak yang lebih sering dijadikan pengungkapan favorit oleh perusahaan. Untuk indikator yang membahas mengenai jumlah angkatan kerja menurut jenis pekerjaan, kontrak pekerjaan, dan wilayah. sedangkan untuk indikator yang membahas mengenai program pendidikan, pelatihan, penyuluhan / bimbingan, pencegahan, dan pengendalian risiko setempat untuk membantu para karyawan, anggota keluarga dan anggota masyarakat, mengenai penyakit berat/berbahaya. Pada indikator yang juga membahas mengenai masalah kesehatan dan keselamatan yang tercakup dalam perjanjian resmi dengan serikat karyawan. Hal ini menandakan bahwa pada praktek tenaga kerja dan pekerjaan yang layak yang lebih difavoritkan dalam pengungkapan informasi pelaporan adalah tentang kepedulian kesehatan dan keselamatan tenaga kerja.

$$
\text { Pada penelitian ini }
$$
memberikan informasi bahwa hampir semua perusahaan BUMN dan BUMS yang terdaftar di Bursa Efek Indonesia, telah melakukan program CSR. Program CSR yang dilakukan perusahaan lebih banyak diarahkan pada sektor ekonomi, lingkungan dan ketenagakerjaan. Program CSR merupakan investasi bagi perusahaan demi pertumbuhan dan keberlanjutan perusahaan dan bukan lagi dilihat sebagai sarana biayamelainkan sebagai sarana meraih keuntungan. Program CSR merupakan komitmen perusahaan untuk mendukung terciptanya pembangunan berkelanjutan yang ada di Indonesia.

Hasil penelitian ini sebagian mendukung penelitian dari penelitian Janah (2013), di 
manatemuan penelitian menunjukkan bahwa terdapat perbedaan yang signifikan pada pelaksanaan dan pengungkapan CSR antara bank pemerintah dan swasta, perbedaan ini terjadi untuk keseluruhan total pengungkapan maupun untuk masing-masing dari enam indikator GRI. Pada penelitian ini hanya indikator ketenagakerjaan yang memiliki perbedaan, di mana CSR perusahaan BUMN di sektor ketenagakerjaan lebih besar dibandingkan perusahaan BUMS, dan perbedaan CSR ini dinilai sangat signifikan.

\section{PENUTUP}

\section{Kesimpulan}

Berdasarkan hasil pengujian di bab sebelumnya, maka dapat diambil beberapa kesimpulan sebagai berikut:

1. Tidak terdapat perbedaan yang signifikan antara Corporate Social Responsibility (CSR) dari perusahaan BUMN dengan perusahaan BUMS ditinjau dari sektor ekonomi. Dari analisis deskripsi menunjukkan bahwa CSR perusahaan BUMN di sektor ekonomi lebih besar dibandingkan perusahaan BUMS, akan tetapi perbedaan tersebut dinilai kurang signifikan.

2. Tidak terdapat perbedaan yang signifikan antara Corporate Social Responsibility (CSR) dari perusahaan BUMN dengan perusahaan BUMS ditinjau dari sektor lingkungan. Dari analisis deskripsi menunjukkan bahwa CSR perusahaan BUMN di sektor lingkungan lebih besar dibandingkan perusa-haan BUMS, akan tetapi perbedaan tersebut dinilai kurang signifikan.

3. Terdapat perbedaan yang signifikan antara Corporate Social Responsibility (CSR) dari perusahaan BUMN dengan perusahaan BUMS ditinjau dari sektor ketenagakerjaan. Dari analisis deskripsi menunjukkan bahwa CSR perusahaan BUMN di sektor ketenagakerjaan lebih besar dibandingkan perusahaan BUMS, dan perbedaan CSR ini dinilai sangat signifikan.

\section{Saran}

Dari beberapa uraian dan penjelasan yang telah dipaparkan oleh peneliti, adapun saran dari peneliti yaitu:

1. Pemerintah perlu memberikan penjabaran terhadap dasar hukum CSR ke dalam aturan-aturan yang pada filosofi CSR, yaitu tanggung jawab terhadap pelestarian sumberdaya alam sebagai penopang keberlanjutan kehidup-an, untuk penyamaan persepsi tentang urgensi dan permasalahan dalam operasionalisasi kegiatan CSR.Pemerintah juga diharapkan dapat memfasilitasi pelaksanaan CSR oleh perusahaan, dengan tanpa membatasi kepentingan perusahaan terkait dengan CSR. Bentuk fasilitasi pemerintah dapat berupa fasilitasi perijinan pelaksanaan CSR, penyediaan data, sosialisasi tentang CSR kepada masyarakat, dan sharing program.

2. Peneliti selanjutnya dapat menambahkan sampel perusahaan dan dapat menambah periode tahun penelitian, tidak hanya satu tahun saja.Sehingga hasil yang didapat lebih akurat. 
3. Bagi Perusahaan

a. Perusahaan BUMN

Perusahaan BUMN seharusnya lebih meningkatkan kegiatan CSR nya, dalam penerapan program CSR perusahaan BUMN seharusnya tidak semata-mata hanya karena undang-undang yang mengatur, namun seharusnya perusahaan melakukannya karena adanya keperdulian terhadap masyarakar sekitar serta lingkungannya.

b. Perusahaan BUMS

Perusahaan BUMS seharusnya lebih meningkatkan penerapan kegiatan program CSR nya.

\section{DAFTAR PUSTAKA}

Anofrida Yenti.2014. Pengaruh Penerapan Program Corporate Social Responsibility terhadap Citra Perusahaan PT. Semen Padang (Studi Kasus Masyarakat Kecamatan Lubuk Kilangan Padang). Fakultas Ekonomi Universitas Negeri Padang

Nanda Febrina Wahyu Safitri. 2013. Analisa Pelaporan Pengungkapan Corporate Social Sesponsibility (CSR) berdasarkan pedoman Global Reporting Initiatives (GRI). Universitas Negeri Surabaya

Fauzi et al . 2007. Pengaruh Struktur kepemilikan Terhadap CSR Perusahaan BUMN. Jurnal

Yuniarti. 2007. Pengungkapan Corporate Social Responsibility (CSR) pada Perbankan BUMN. Jurnal

Dalina. 2014. Analisis Pengungkapan Corporate Social Responsibility (CSR) pada Perusahaan BUMN yang Terdaftar di Bursa Efek Indonesia Periode 2013. Universitas Negeri Surabaya

Arvina Arief. 2014. Pengaruh Pengungkapan Corporate Social Responsibility terhadap Manajemen Laba (Studi Kasus Pada Perusahaan Non Keuangan dan Jasa yang Terdaftar di BEI tahun 2010-2012). Fakultas Ekonomi Universitas Diponegoro

Soliman et al. 2012. Analisis Hubungan Penilaian CSR dengan Kepemilikan Perusahaan Pada BUMN. Jurnal

Indrawati. 2012. Pengungkapan CSR dalam Annual Report padaPerusahaan Manufaktur Yang Terdaftar di BEI. Jurnal

Mohd. Ghazali. 2007. Pengaruh Struktur Kepemilikan Terhadap Pelaporan CSR pada Perusahaan Semen Yang Terdaftar di BEI. Jurnal

Harmoni dan Andriyani. 2008. Pengungkapan Corporate Social Responsibility (CSR) pada official website perusahaan pada perusahaan Unilever. Jurnal

Janah. 2013.Analisis Perbedaan pengungkapan Corporate Social Responsibility (CSR) pada Bank, Pemerintahan dan Swasta Yang Terdaftar di BEI. Jurnal

Rachman .2013. Analisis Perbedaan Pengungkapan Corporate Social Responsibility (CSR) pada Perusahaan Indrustri 
Utama dan Sekunder Yang

Terdafatar di BEI. Jurnal

Undang-Undang Republik Indonesia

Nomor 40 tahun 2007

tentang Perseroan Terbatas

pasal 74 ayat 1

Undang-Undang Nomor 25 tahun

2007 tentang Penanaman

Modal pasal 15 (b)

UU No.40 pasal 66 ayat 2 tahun

2007 
